Canadian Journal of Plant Science Revue canadienne de phytotechnie

\title{
Repetitive Vegetative propagation of first-year sea buckthorn (Hippophae rhamnoides L.) cuttings
}

\begin{tabular}{|r|l|}
\hline Journal: & Canadian Journal of Plant Science \\
\hline Manuscript ID & CJPS-2017-0039.R4 \\
\hline Manuscript Type: & Article \\
\hline Date Submitted by the Author: & 01-Sep-2017 \\
\hline Complete List of Authors: & $\begin{array}{l}\text { Dale, Adam; University of Guelph, Plant Agriculture } \\
\text { Galic, Dragan; University of Guelph, Plant Agriculture }\end{array}$ \\
\hline Keywords: & sea buckthorn, cutting propagation, chilling \\
\hline
\end{tabular}

SCHOLARONE $^{\text {tw }}$
Manuscripts 


\title{
Repetitive vegetative propagation of first-year sea buckthorn
}

\section{(Hippophae rhamnoides L.) cuttings}

\author{
Adam Dale ${ }^{1,2}$, and Dragan Galić ${ }^{1}$ \\ ${ }^{1}$ Department of Plant Agriculture, University of Guelph, Simcoe Research Station, \\ Simcoe, Ontario, Canada, N3Y 4N5. \\ ${ }^{2}$ Corresponding author (e-mail:adale@uoguelph.ca)
}

Dale A. and Galić D. 2016. Vegetative propagation of sea buckthorn (Hippophae rhamnoides L.). Can. J. Plant Sci. .... Sea buckthorn (Hippophae rhamnoides L.) is used in beverages, pharmaceuticals, cosmetic products and animal feeds. Although Seabuckthorn has been shown to be easy to propagate vegetatively, currently, there is little information on reliable techniques to vegetatively propagate the plant repetitively within a single year. To address this, three experiments were conducted to study whether season and chilling affected the successful rooting of cuttings. Four cultivars, Chuskaya, Golden Rain, Lord, and Sunny were used in the season- and chilling-effect experiments. Hardwood and softwood cuttings from field-grown plants did not root from October to December. The percent of rooted cuttings in January was cultivar dependent. The number and percent of rooted greenhouse produced cuttings were significantly affected by length of chilling. Most cuttings were produced, and the highest percent rooted when the plants chilled for at least 6 weeks. Lord had the most and Golden Rain the least 
number of rooted cuttings. This study indicated that greenhouse grown stock plants were a viable source of sea buckthorn cuttings for vegetative propagation. When combined with field-grown sources it is possible to produce sea buckthorn planting material year round.

Key Words: sea buckthorn, cutting propagation, chilling

\section{INTRODUCTION}

Horticultural plants including sea buckthorn have been an indispensable part of human life for ages. Ever since ancient times, their fruits, seeds, even roots and branches, have been used to meet personal and social needs such as serving food, curing diseases and beautifying the planet (Ercisli 2009; Erturk et al. 2010; Yazici and Sahin 2016).

Sea Buckthorn (Hippophae rhamnoides L.) is a perennial shrub which produces small yellow flowers in the spring, and bears yellow or orange berries in the fall. The fruit has been used for many centuries as a source of vitamins, minerals and essential oils. The species is a colonizer of open habitats, and its roots have nodules that contain the nitrogen-fixing bacterium Frankia sp. (Gordon and Dawson 1979).

It is native throughout Europe, the Caucasus and central Asia and was originally imported into Canada in 1938 and has been used extensively in the Prairie Provinces for wildlife habitat, farmstead protection, erosion control and marginal land reclamation (Li and Schroeder 1996). However, in Canada, it is not in large scale commercial production for its fruit products. 
Sea Buckthorn has many potential uses (Li and Schroeder 1996; Li and Beveridge 2003; Zeb 2004). The plant is widely adapted, grows well on poor, welldrained soils, such as sands or gravels, grows rapidly, can be coppiced readily and suckers well. This makes it ideal for erosion control and land reclamation (Huang et al. 2006). It has also been used for timber production in Nepal (Li and Beveridge 2003) and has the potential for biomass production (Warnock and Miskin 2009).

The high cost of hand-harvesting appears to be one factor which limits its development in Europe and North America. Consequently, attempts have made to develop mechanical harvesters (Varlamov and Gabuniya 1990; Mann et al. 2003). However, these have only been partially successful and are cultivar dependent (Mann et al. 2001) because many cultivars have sessile fruit with a poorly defined abscission layer (Li and Beveridge 2003).

Many of the plantings worldwide have been seedlings for environmental control. Since, the plant is dioecious (male and female plants), the seedlings are extremely variable, which leads to inconsistent products if the fruit are used for nutritional and medicinal purposes. For horticultural production superior cultivars are required. Breeding programs have been successful at providing superior cultivars, but their availability in Canada is limited. Superior cultivars can then be vegetatively propagated to give uniform orchards ( $\mathrm{Li}$ and Beveridge 2003).

Sea buckthorn is propagated successfully by soft- and hardwood cuttings ( $\mathrm{Li}$ and Beveridge 2003). However, the success rate appears to depend on which season of the year the cuttings are taken. Also cuttings often grow slowly and their ability to root is dependent on the season (Li and Beveridge 2003). Hardwood cuttings collected between 
October and March can be rooted successfully, provided those collected before March are stored below $0^{\circ} \mathrm{C}$ (Singh and Gupta 2003). Various authors have reported that softwood cuttings collected from late May through to the beginning of August were rooted successfully (Singh and Gupta 2003).

This study was conducted to study whether the season and chilling affected the successful rooting of cuttings and their ability to produce more cuttings.

\section{MATERIALS AND METHODS}

\section{Effect of Season on Rooting Ability}

First-year cuttings, about $30 \mathrm{~cm}$ long, 2.0-4.5 mm diameter, were taken from four Sea Buckthorn cultivars, Chuskaya, Golden Rain, Lord and Sunny grown at The Healing Arc's Farm, Wingham, Ontario, Canada. Bundles of 25 cuttings were wrapped in wet paper, refrigerated overnight, and transported the next day to the University of Guelph, Simcoe Research Station, Simcoe, Ontario, Canada in plastic pails with a little water at the bottom.

Cuttings were taken 7 July 2004, 12 August 2004, 22 September 2004, 27 October 2004, 25 November 2004, 21 December 2004, 26 January 2005 and 13 April 2005.

Cuttings of similar diameter were trimmed to $10 \mathrm{~cm}$ with a slanting cut at the bottom and straight cut on the top, leaves were removed from the bottom $3 \mathrm{~cm}$, and the cuttings dipped 5 to $7.5 \mathrm{~mm}$ for $5 \mathrm{sec}$. into $0.5 \%$ indole-3-butyric acid (Stim-root 5000, Plant Products C. Ltd., Brampton, Ontario, Canada). They were then planted at least two buds deep into $39 \mathrm{~mm}$ diameter x $120 \mathrm{~mm}$ deep 45-cell packs in two parts perlite and one part 
peat moss, were rooted on a propagation bed under intermittent mist in a greenhouse maintained at a minimum of $18{ }^{\circ} \mathrm{C}$ for four weeks, and then grown in pots in the greenhouse for twenty weeks.

After, the cuttings were rooted they were transplanted into $63 \times 70 \times 240 \mathrm{~mm}$ pots in a mixture of peat moss, vermiculite, perlite, dolomite limestone, and bentonite clay (Professional Mix VPW 30, ASB Greenworld, Mt. Elgin, Ontario, Canada). The plants were regularly watered and fertilized with $0.5 \mathrm{~g} \mathrm{~L}^{-1}$ of 20:20:20 water soluble fertilizer (Plant Products Co. Ltd., Brampton, Ontario, Canada).

At planting, the basal diameter of 10 cuttings of each cultivar was measured. After four weeks, the number of rooted cuttings was recorded. After 24 weeks, the number of new shoots and their shoot length and the total root length and root dry weight were measured for ten randomly selected plants. For the root characteristics, the plants were stored between $3-5{ }^{\circ} \mathrm{C}$ until the roots were measured. Then, the roots were rehydrated by soaking in water and separated from the soil using a mechanical procedure outlined by Böhm (1979). The length of each individual root was measured and then they were dried at $80{ }^{\circ} \mathrm{C}$ to constant weight.

\section{Effect of Chilling on Propagation Ability}

Twenty plants of each of the four cultivars planted on 7 July 2004 in the first experiment were used. Five plants of each cultivar were given $0,4,6,8,10$ weeks of chilling. On 26 November 2004, plants for chilling treatments were moved to a cooler at 1.4 to $2.7^{\circ} \mathrm{C}$ and the plants with no chilling where left in the greenhouse. The plants of 4 , 6,8 , and 10 weeks of chilling treatments were moved out of the cooler on 24 December 2004, 13 January 2005, 21 January 2005 and 4 February 2005, respectively. 
After the chilling treatment, the plants were grown in the greenhouse and used as the source of cutting material. In the greenhouse, plants were maintained as in the previous experiment. Cuttings were taken from shoots at least $12 \mathrm{~cm}$ long every 2 weeks from 26 November 2004 to 23 December 2005. Cuttings were taken from both the original plants and any rooted cuttings and at least one lateral bud was left at the base of each branch. All cuttings were cut and/or trimed to $10 \mathrm{~cm}$ and dipped into liquid $0.5 \%$ indole-3-butyric acid (Stim-root 5000, Plant Products C. Ltd., Brampton, Ontario, Canada) and were planted into $29 \mathrm{~mm}$ diameter x $115 \mathrm{~mm}$ deep 57-cell packs in Professional Mix VPW 30, (ASB Greenworld, Mt. Elgin, Ontario, Canada). The cell packs were kept in plastic containers $710 \mathrm{~mm}$ length $\times 500 \mathrm{~mm}$ with $\times 330 \mathrm{~mm}$ depth covered with slightly perforated lid. The bottoms of the plastic containers were filled with water; the humidity was maintained between 65 and $70 \%$, and ambient temperature between 23 and $25{ }^{\circ} \mathrm{C}$. The cell packs were kept above the water level. The cuttings were occasionally misted throughout the day. Supplemental bottom heat was provided. At planting, the number of cuttings and their basal diameter were recorded, and after four weeks each cutting was classified as rooted or unrooted. Then rooted cuttings were removed from the propagation boxes and each cultivar consolidated. Then twenty five plants of each cultivar were randomly selected and the growth recorded as in the previous experiment.

\section{Effect of Chilling on Rooting of Chuskaya and Sunny Cuttings}

Plants of Chuskaya and Sunny from the previous experiment were moved outside on 1 June 2005. These two cultivars were chosen, as Chuskaya needed most chilling days to break dormancy and Sunny the least in the first experiment. One hundred and twenty, $30 \mathrm{~cm}$ cuttings of each cultivar were taken on 16 November 2005 with approximately 
uniform diameter placed in bundles of 20 and placed in damp sand and chilled for $0,4,6$, 8, 10 and 12 weeks at 1.4 to $2.3{ }^{\circ} \mathrm{C}$. After the cuttings were removed from the chilling treatment, they were dipped into $0.5 \%$ indole-3-butyric acid(Stim-root 5000, Plant Products C. Ltd., Brampton, Ontario, Canada), and planted $10 \mathrm{~cm}$ deep into $38-55 \mathrm{~mm}$ diameter x 130 mm deep-cell packs in Professional Mix VPW 30, (ASB Greenworld, Mt. Elgin, Ontario, Canada). All experimental details were as described in the second experiment. After chilling the diameter of the cuttings were measured. After six weeks, the number of rooted cuttings were recorded, the number of new shoots and roots counted, and their average length calculated.

Each of the experiments were randomized complete blocks with four replications. There were four cultivars, two in the last experiment. Data were analyzed using analysis of variance (PROC GLM) (SAS Institute Inc, version 9.4). If discontinuous variables differed significantly the means were separated with Duncan's Multiple Range Test. When continuous variables and their interactions were significant, regression lines were calculated.

\section{RESULTS}

\section{Effect of Season on Rooting Ability}

All cuttings of all the four cultivars rooted successfully until 22 September. Thereafter, most cuttings did not root until 26 January when Sunny and Lord rooted successfully (Table 1). In October, November and December, the cuttings callused but did not root. 
The diameter of the shoots varied significantly for cultivar, date and their interaction. The cutting diameter appeared to increase from early summer of 2004 to spring of 2005 . The large diameters of the December collection may be a sampling error when the shoots were cut (Figure 1). Lord had significantly thinner cuttings (Table 2) and the cultivar $\mathrm{x}$ date interaction showed no consistent trends (data not shown).

The number of shoots produced on each cutting, their average length, average root length and dry weight all varied significantly for date, but only number of shoots and total root dry weight varied significantly for cultivar, and only root length varied significantly for date x cultivar interaction. The cuttings taken in August and September grew more slowly than those taken in July 2004 and January and April 2005 (Table 3), probably because of the summer heat in the greenhouse. Also, the shoots grew more than twice as fast in January and April 2005 than on the other dates. Cuttings of Lord and Chuskaya appeared to be more vigorous as they had more shoots and Lord had a greater root dry weight than Golden Rain and Sunny (Table 2).

\section{Effect of Chilling on Propagation Ability}

Total number of rooted cuttings, percent of rooted cuttings varied significantly only for chilling; the cultivars varied significantly for all variables except percent of rooted cuttings. The chilling x cultivar interaction did not differ significantly. The longer the chilling time the fewer the number of days that the cuttings took to root (Figure 2). Chilling significantly improved the number of cuttings produced, and the number and percentage of cuttings rooted (Table 4). The length of chilling only had a minor effect on the production and rooting of the cuttings. Chilling increased the rooting ability of the cuttings from mid-February to the end of October (Figure 3). The percent of rooting was 
very high and consistent for all four chilling times from mid-February to end of June, thereafter rooting was less reliable. Lord had significantly thinner cuttings and produced significantly more cuttings and rooted cuttings (Table 5).

\section{Effect of Chilling on Rooting of Chuskaya and Sunny Cuttings}

All the characteristics measured varied significantly for chilling and cultivar, except that root length did not vary significantly between cultivars (Tables $6 \& 7$ ). Only the percent of rooted cuttings varied significantly for the chilling $\mathrm{x}$ cultivar interaction.

Chuskaya had greater percent rooted cuttings after four weeks than Sunny, which indicated that Chuskaya had obtained sufficient chilling after four weeks while Sunny had sufficient chilling after 6 weeks (Figure 4). Sunny had fewer percent rooted cuttings after 10 and 12 weeks. Greater chilling resulted in more vigorous plants (Table 6). Chuskaya on average, had thicker cutting stems, more, longer shoots, more roots (Table 7).

\section{DISCUSSION}

Sea buckthorn can be successfully propagated from softwood cuttings taken from fieldgrown plants or stock plants grown in a greenhouse. Cuttings were rooted successfully throughout the growing season, and this ceased when the plants became dormant. Once the plants had received six to eight weeks chilling, cuttings taken from stock plants were able to be rooted successfully with an average $80 \%$ success rate for up to eight months in a greenhouse.

The rooting success is similar to that reported in previous work (Singh and Gupta 2003). In Tajikistan, over $96 \%$ rooting was achieved with softwood cuttings (Avdeev 1976), 
and over $86 \%$ rooting with hardwood cuttings taken just before bud break (Avdeev 1984). In British Columbia, 90\% of hardwood cuttings rooted when taken in mid-March (Li and Schroeder 1996). However, Avdeev (1976) noted that cuttings taken during intensive growth rooted less successfully and this varied among cultivars.

The successful rooting of cuttings was affected by the environmental conditions in the greenhouse, and this was also influenced by the cultivar used. From June through to September the greenhouse was very hot. Also, later in the year, the cooler temperatures and shorter days induced dormancy. This can be reduced or postponed if the daylength is extended with supplemental light, and the temperature the greenhouse maintained at about $20^{\circ} \mathrm{C}$.

The size and age of the stock plants will determine the number of cuttings collected. We were able to use four to six month old rooted cuttings to produce a year-round supply. However, we only collected four cuttings from each plant, about one every three months. If two or three year-old stock plants had been used, the plant could be trained to an architecture that would enable many more cuttings per plant to be harvested.

The six to eight weeks chilling treatment shows that the plant's requirement to break dormancy is similar to that found other perennial crops, for example raspberries (Dale et al., 2003). Also, in our experiments in southern Ontario, cuttings from plants chilled indoors rooted successfully about two months before plants that were chilled in the field. In the greenhouse, the production of the cuttings was compounded by taking cuttings from rooted cuttings once they reached sufficient size. It was calculated that this gave about an eight times greater production rate compared to outside propagation. In the greenhouse rooted cuttings were produced consistently for nine months (February to 
October) compared to three months outside (July to September), with one rooted cutting about every six weeks (Table 1, Figure 3). Although the costs involved with this type of propagation strategy have not been examined, the combinations of the extended growing season and the use of the rooted cuttings gave a much faster propagation rate.

We were able to show that cuttings could be produced and rooted year round, and this was improved if the stock plants were suitably chilled for six to eight weeks, depending on the cultivar. The rate at which cuttings would be produced could be improved considerably if additional research into the environmental conditions during the growing season, and different plant management techniques of the stock plants was conducted.

\section{ACKNOWLEDGMENTS}

The authors acknowledge the financial support of the Agricultural Adaptation Council through its Canadapt program.

\section{REFERENCE}

Avdeev, V.I. 1976. Propagation of Hippophe rhamnoides by softwood cuttings under mist. Kratkie Tezisy Dokl 2-I Vses. Konf. Molodych Uchenjkh po Sadovstvu (1976) 7274. (Hort. Abstr. 48:318).

Avdeev, V.I. 1984. Propagation of fruit crops by cuttings in upper Tadjikistan. Intensivnye Sposoby Vyrashchivaniya Posadochnogo Materiala Sadovykh Kultur (1984):51-56. (Hort. Abstr. 55:40).

Böhm, W. 1979. Methods of studying of root systems. Springer-Verlag, Berlin. 188pp.

Dale, A., Sample, A., and King, E. 2003. Breaking dormancy in red raspberries for greenhouse production. HortScience 38:515-519.

Ercisli, S., 2009. Apricot culture in Turkey. Scientific Research and Essays 4 : 715-719.

Erturk, Y., Ercisli, S., Haznedar, A., and Cakmakci R. 2010. Effects of plant growth promoting rhizobacteria (PGPR) on rooting and root growth of kiwifruit (Actinidia deliciosa) stem cuttings. Biol. Res. 43: 91-98. 
Gordon, J.C., and Dawson, O.J. 1979. Potential uses of nitrogen-fixing trees and shrubs in commercial forestry. Botanical Gazette, Symbiotic Nitrogen Fixation in Actinomycete -Nodulated Plants (Mar.), 140(Suppl): S88-S90.

Huang, Z.L., Chen, L.D., Fu, B.J., Lu, Y.H., Huang, Y.L., and Gong, J. 2006. The relative efficiency of four representative crop land conversions in reducing water erosions: evidence from long-term plots in the loess hilly area. China Land Degrad. and Dev. 17:615-627.

Li, T.S.C., and Beveridge, T.H.J. 2003. Sea Bucktnorn (Hippophae rhamnoides L.): Production and Utilization. NRC Research Press, Ottawa, Ontario. 133pp.

Li T.S.C., and Schroeder, W.R. 1996. Sea buckthorn (Hippophae rhamnoides L.): a multipurpose plant. HortTechnology 6:370-380.

Mann, D.D., Petkau, D.S., Crowe, T.G., and Schroeder, W.R. 2001. Removal of sea buckthorn (Hippophae rhamnoides L.) berries by shaking. Can. Biosystems Engineering 43:23-27.

Mann, D.D., Petkau, D.S., and Crowe T.G. 2003. Evaluation of a prototype sea buckthorn leaves harvester. Can. Biosystems Engineering 45: 209-2015.

Singh, V., and Gupta, K.R. 2003. Propagation of sea buckthorn (Hippophae rhamnoides L.). In Singh, V. (Ed.) Seabuckthorn (Hippophae L.): A multipurpose wonder plant. Indus Publishing Company, New Deljhi, India. 315-333.

Varlamov, Y.S., and Gabuniya, G.V. 1990. Picking Sea buckthorn fruit by suction air stream. Traktory i sel'skokhozyaistvennye Mashiny 1:29-30 (English abstract).

Warnock, M., and Miskin, D. 2009. Sea buckthorn (Hippophae rhamnoides L.): A review and its potential as a crop in Scotland. Recent Progress in Medicinal Plants 24Standardization of herbal /Ayurvedic Formulations pp. 257-272.

Yazici, K., and Sahin, A. 2016.Characterization of pomegranate (Punica granatum L.) hybrids and their potential use in further breeding. Turkish Journal of Agriculture and Forestry 40: 813-824.

Zeb, A. 2004. Important therapeutic uses of sea buckthorn (Hippophae): a review. J. Biol. Sci. 4:687-693. 
Figure 1. Average cutting diameter for sea buckthorn cultivars during 7 July 2004 to 13 April 2015, Cutting diameter $=2.52+0.0128 *$ Cutdate $-0.0000413 *$ Cutdate $^{2}, \mathrm{R}^{2}=0.32$, $P<0.0001$.

Figure 2 Percent rooted cuttings in the first 120 days after chilling for five chilling times for cuttings of sea buckthorn chilled from 26 November to 4 February 2005.

Figure 3. Percent of rooted cuttings of four cultivars of sea buckthorn produced after $0,4,6,8$ and 10 weeks of chilling.

Figure 4. Percent cutting survival of sea buckthorn cultivars Chuskaya and Sunny after six chilling periods, Chuskaya $(\downarrow)$, Survival $=35.4+11.1 *$ Chilling $-0.63 *$ Chilling $^{2}, \mathrm{R}^{2}=0.85, P<0.0181$; Sunny $(\boldsymbol{\Delta}----\boldsymbol{\Delta})$, Survival $=20.4+14.54 *$ Chilling $-1.00 *$ Chilling ${ }^{2}, \mathrm{R}^{2}=0.85, P<0.0388$. 
Table 1. Percent survival of cuttings of four sea buckthorn cultivars taken from field grown plants in Wingham, Ontario.

\begin{tabular}{lllll}
\hline \multirow{2}{*}{ Cut Date } & \multicolumn{3}{c}{ Cultivar $(\%)$} \\
\cline { 2 - 5 } & Sunny & Lord & Golden Rain & Chuskaya \\
\hline 7 July 2004 & 100 & 100 & 100 & 100 \\
12 August 2004 & 100 & 100 & 100 & 100 \\
22 September 2004 & 100 & 100 & 100 & 100 \\
27 October 2004 & 0 & 0 & 0 & 10 \\
25 November 2004 & 20 & 0 & 0 & 0 \\
21 December 2004 & 0 & 0 & 0 & 0 \\
26 January 2005 & 100 & 100 & 40 & 0 \\
13 April 2005 & 100 & 100 & 100 & 100 \\
\hline
\end{tabular}


Table 2. Basal diameter, number of shoots and root dry weight of rooted cuttings of four sea buckthorn cultivars taken during 7 July 2004 to 13 April 2005 from field grown plants in Wingham, Ontario.

\begin{tabular}{llll}
\hline Variable & $\begin{array}{l}\text { Cutting } \\
\text { diameter } \\
(\mathrm{mm})\end{array}$ & $\begin{array}{l}\text { Number } \\
\text { of shoots }\end{array}$ & $\begin{array}{l}\text { Root dry } \\
\text { weight } \\
(\mathrm{g})\end{array}$ \\
\hline Lultivar & $3.0 a$ & $3.7 a$ & $1.0 a$ \\
Chuskaya & $3.2 b$ & $3.4 a$ & $0.7 b$ \\
Sunny & $3.2 b c$ & $2.5 b$ & $0.7 b$ \\
Golden Rain & $3.3 c$ & $2.7 b$ & $0.6 b$ \\
\hline
\end{tabular}

Note: Mean separation within columns by Duncan's Multiple Range Test $(\mathrm{P}<0.05)$ 
Table 3. Average number of shoots, shoot and total root length and root dry weight of rooted cuttings of four sea buckthorn cultivars taken during 7 July 2004 to 13 April 2005 from field grown plants in Wingham, Ontario.

\begin{tabular}{lllll}
\hline Cut date & $\begin{array}{l}\text { Number } \\
\text { of shoots }\end{array}$ & $\begin{array}{l}\text { Average } \\
\text { shoot } \\
\text { length } \\
(\mathrm{mm})\end{array}$ & $\begin{array}{l}\text { Root } \\
\text { length } \\
(\mathrm{mm})\end{array}$ & $\begin{array}{l}\text { Root dry } \\
\text { weight } \\
(\mathrm{g})\end{array}$ \\
\hline 07 Jul 04 & 4.3 & 99 & 348 & 1.2 \\
12 Aug 04 & 3.1 & 55 & 265 & 0.2 \\
22 Sep 04 & 2.1 & 72 & 234 & 0.1 \\
26 Jan 05 & 2.2 & 224 & 340 & 0.6 \\
13 Apr 05 & 3.4 & 235 & 452 & 1.7 \\
$P=$ & $<0.0001$ & $<0.0001$ & $<0.0001$ & $<0.0001$ \\
\hline
\end{tabular}

Note: October, November and December cutting dates were removed as there was no growth of the cuttings. 
Table 4. Average total number of cuttings taken, and percent of rooted cuttings per original plant of four sea buckthorn cultivars produced after $0,4,6,8$ and 10 weeks of chilling.

\begin{tabular}{lll}
\hline Week & $\begin{array}{l}\text { Total } \\
\text { number of } \\
\text { cuttings }^{\text {a }}\end{array}$ & $\begin{array}{l}\text { Percent of } \\
\text { cuttings } \\
\text { rooted }\end{array}$ \\
\hline 0 & 75 & 71 \\
4 & 95 & 75 \\
6 & 105 & 80 \\
8 & 102 & 82 \\
10 & 96 & 82 \\
$P=$ & 0.04 & 0.02 \\
\hline
\end{tabular}

Note:The number of cuttings per original plant includes cuttings taken from both the original plant and any of their rooted cuttings 
Table 5. Average cutting diameter, total number of cuttings and number of rooted cuttings of four cultivars produced after $0,4,6,8$ and 10 weeks of chilling

\begin{tabular}{llll}
\hline Cultivar & $\begin{array}{l}\text { Average } \\
\text { cutting } \\
\text { diameter }\end{array}$ & $\begin{array}{l}\text { Total } \\
\text { number of } \\
\text { cuttings }\end{array}$ & $\begin{array}{l}\text { Number of } \\
\text { cuttings } \\
\text { rooted }\end{array}$ \\
\hline Lord & $1.8 b$ & $147 b$ & $115 b$ \\
Sunny & $1.9 a$ & $77 a$ & $60 a$ \\
Chuskaya & $1.9 a$ & $86 a$ & $66 a$ \\
Golden Rain & $1.9 a$ & $69 a$ & $54 a$ \\
\hline
\end{tabular}

Note: Mean separation within columns by Duncan's Multiple Range Test $(\mathrm{P}<0.05)$ 
Table 6. Average cutting diameter and number of shoots, shoot length, number of roots and root length produced by cuttings of sea buckthorn cultivars Chuskaya and Sunny after $0,4,6,8,10$ and 12 weeks of cold storage

\begin{tabular}{|c|c|c|c|c|c|c|c|}
\hline \multirow{2}{*}{$\begin{array}{l}\text { Chilling } \\
\text { (week) }\end{array}$} & \multirow{2}{*}{$\begin{array}{l}\text { Cutting } \\
\text { diameter } \\
(\mathrm{mm})^{\mathrm{a}}\end{array}$} & \multirow{2}{*}{$\begin{array}{l}\text { Number } \\
\text { of } \\
\text { shoots }\end{array}$} & \multirow{2}{*}{$\begin{array}{l}\text { Shoot } \\
\text { length } \\
(\mathrm{mm})\end{array}$} & \multicolumn{3}{|c|}{ Number of roots ${ }^{b}$} & \multirow[b]{2}{*}{$\begin{array}{l}\text { Root } \\
\text { length } \\
(\mathrm{mm})\end{array}$} \\
\hline & & & & Chuskaya & Sunny & Average & \\
\hline 0 & 3.3 & 1.1 & 5 & 2.1 & 1.2 & 1.7 & 26 \\
\hline 4 & 3.1 & 1.8 & 15 & 2.6 & 2.3 & 2.5 & 51 \\
\hline 6 & 3.2 & 1.8 & 10 & 5.2 & 2.5 & 3.9 & 50 \\
\hline 8 & 3.2 & 1.6 & 10 & 3.5 & 2.2 & 3.3 & 57 \\
\hline 10 & 3.2 & 2.1 & 16 & 8.4 & 2.3 & 6.0 & 100 \\
\hline 12 & 3.3 & 2.4 & 16 & 6.3 & 4.1 & 5.4 & 102 \\
\hline$P=$ & 0.036 & $<0.0001$ & $<0.0001$ & $<0.0001$ & 0.0008 & 0.003 & $<0.0001$ \\
\hline
\end{tabular}

${ }^{\mathrm{a}}$ Average of both cultivars

${ }^{\mathrm{b}}$ Interaction of chilling time and cultivar was significant $(P=0.0036)$ 
Table 7.Average cutting diameter and number of shoots, shoot length, number of roots and root length produced by cuttings of sea buckthorn cultivars in six chilling treatments Chuskaya and Sunny.

\begin{tabular}{|c|c|c|c|c|c|}
\hline$\frac{\text { Variable }}{\text { Cultivar }}$ & $\begin{array}{l}\text { Cutting } \\
\text { diameter } \\
(\mathrm{mm})\end{array}$ & $\begin{array}{l}\text { Number } \\
\text { of shoots }\end{array}$ & $\begin{array}{l}\text { Total } \\
\text { shoot length } \\
(\mathrm{mm})\end{array}$ & $\begin{array}{l}\text { Number } \\
\text { of } \\
\text { roots }\end{array}$ & $\begin{array}{l}\text { Root } \\
\text { length } \\
(\mathrm{mm})\end{array}$ \\
\hline Chuskaya & 3.3 & 1.9 & 13.3 & 5.0 & 70.4 \\
\hline Sunny & 3.2 & 1.7 & 10.2 & 2.7 & 64.0 \\
\hline$P=$ & 0.025 & 0.026 & 0.004 & $<0.0001$ & 0.566 \\
\hline
\end{tabular}




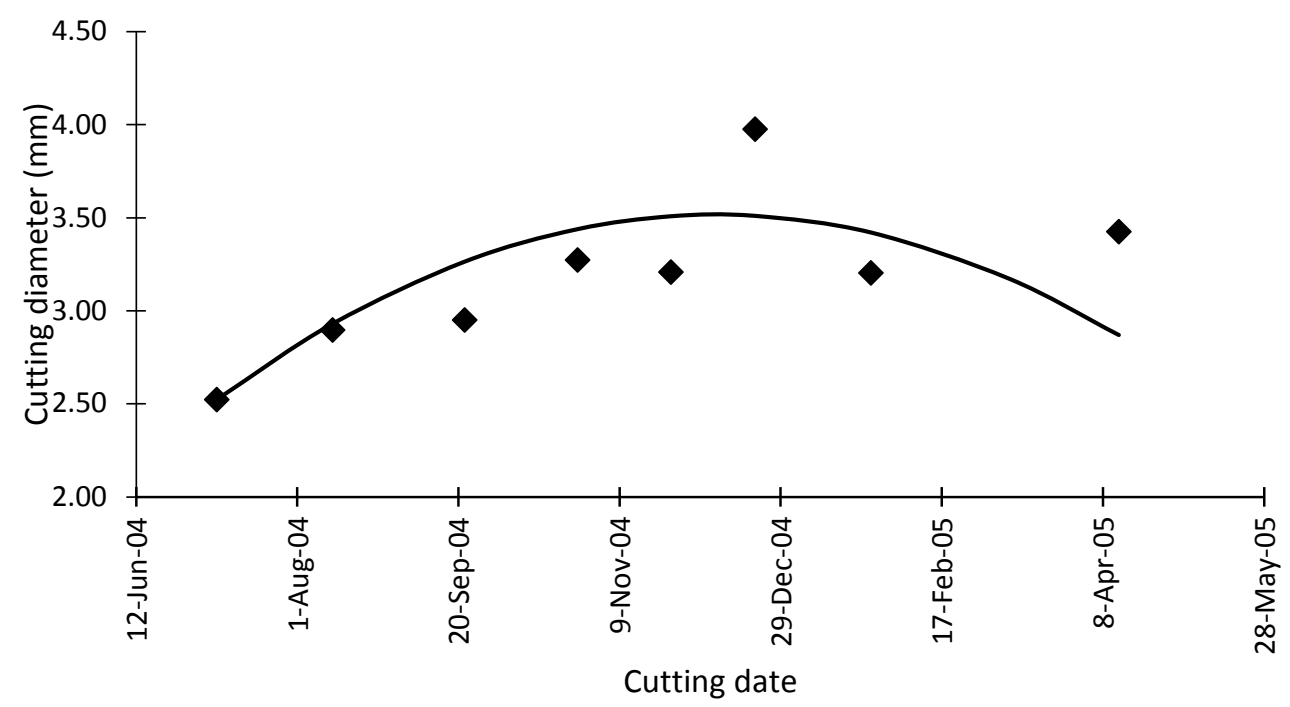

Figure 1. 


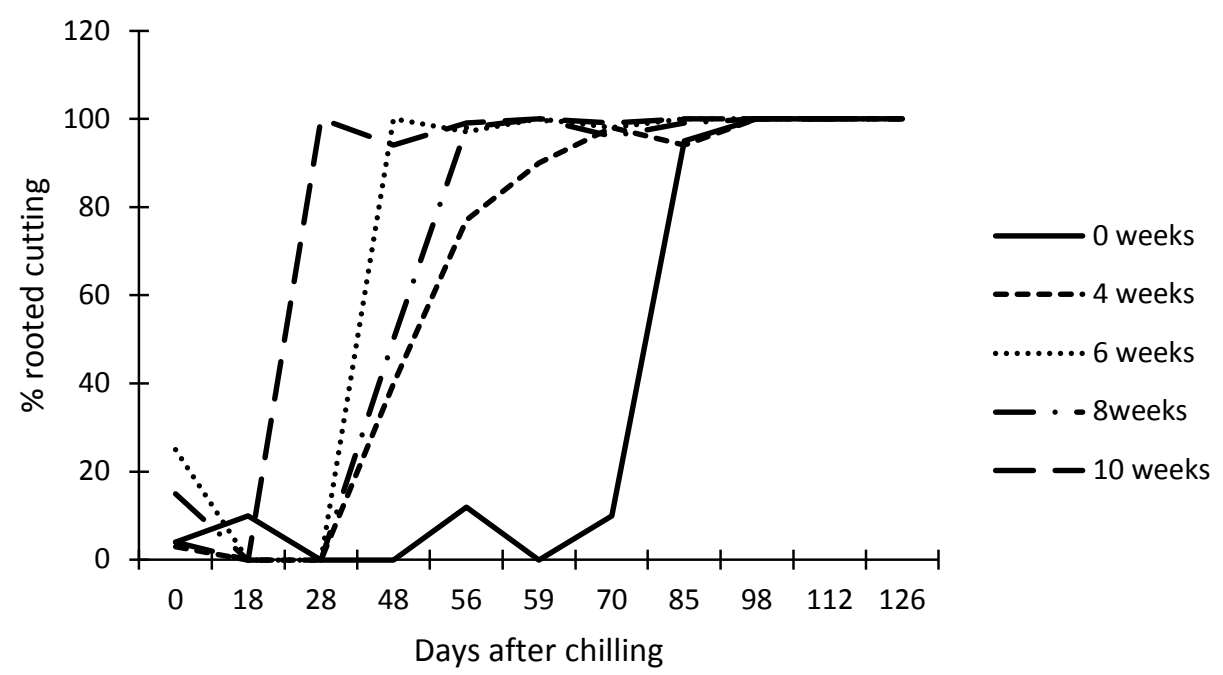

Figure 2 


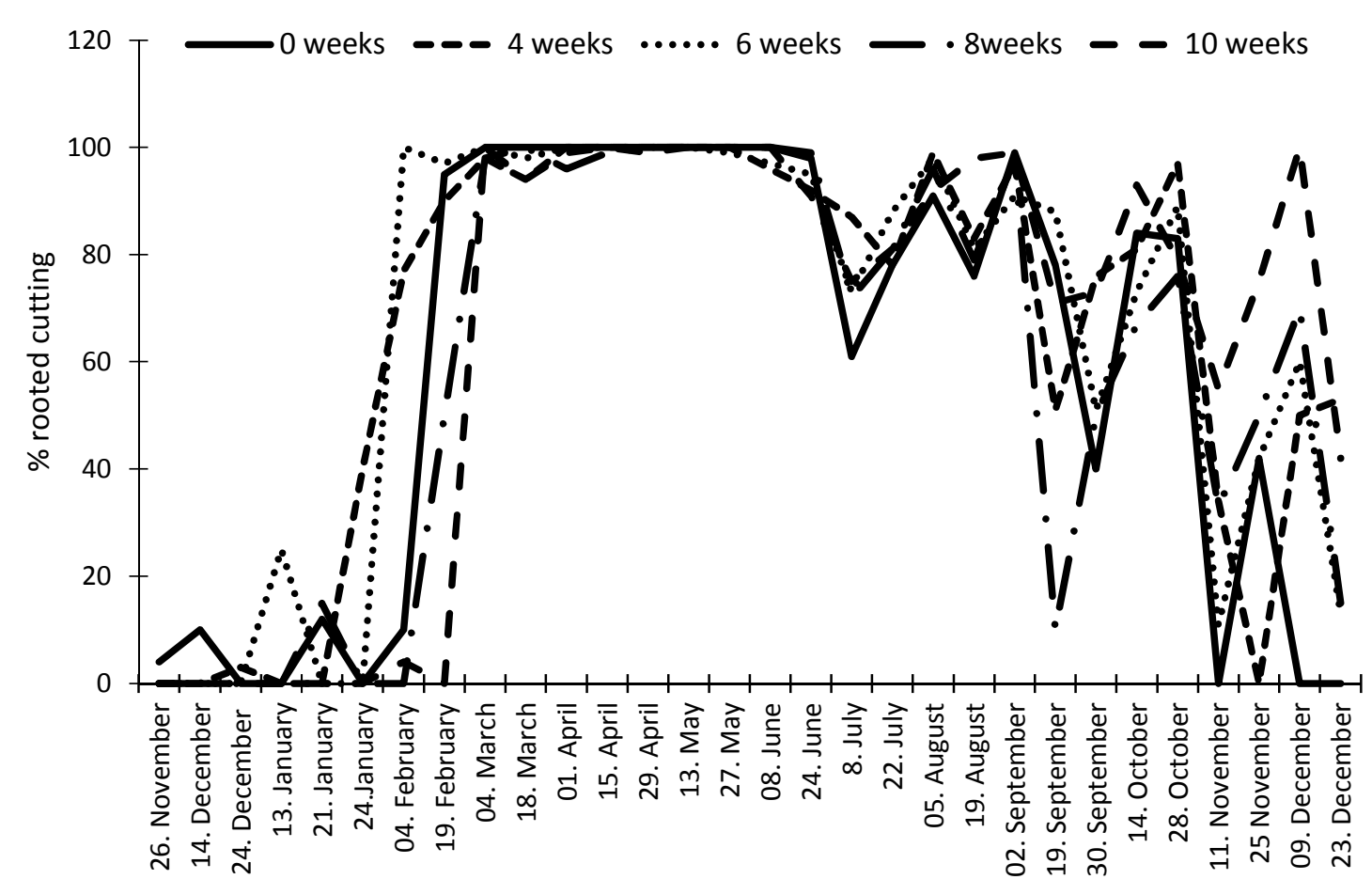

Date cuttings were collected

Figure 3. 
Canadian Journal of Plant Science

Page 24 of 24

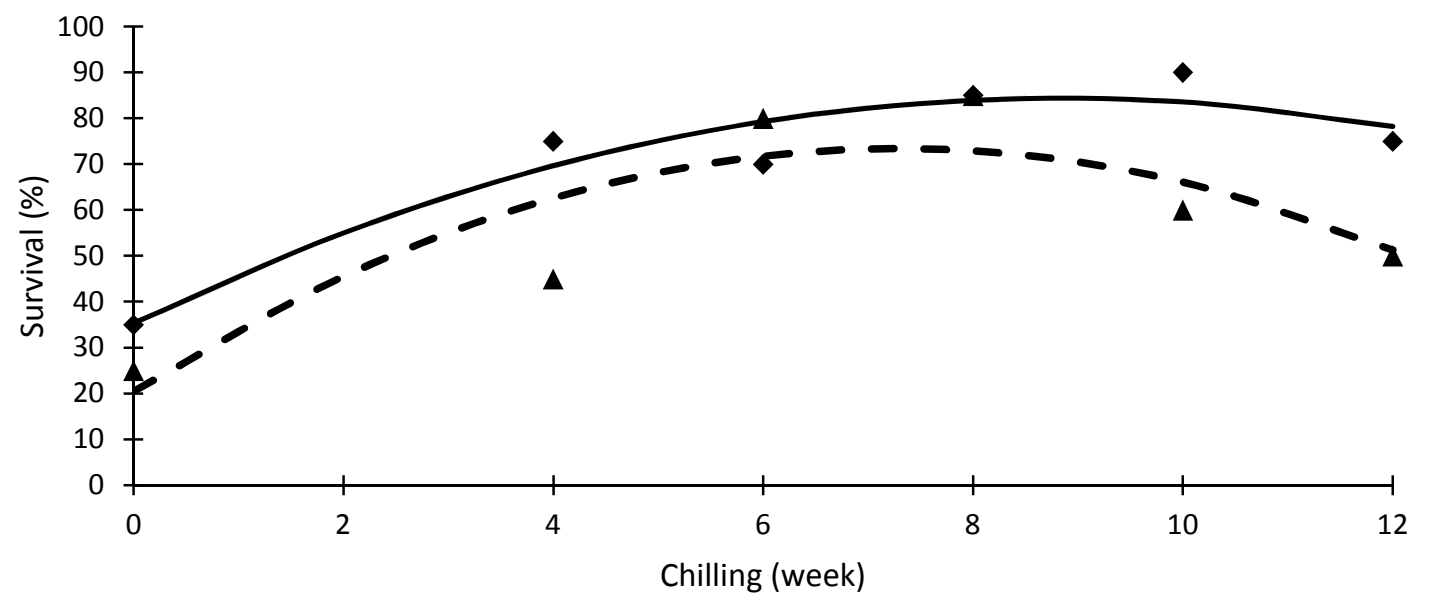

Figure 4.

https://mc.manuscriptcentral.com/cjps-pubs

4 